\title{
EVALUATION OF MEDICAL TOURISM IN PUBLIC HOSPITAL SERVICES
}

\author{
İrfan Özcan ${ }^{1}$ \\ Emine Erdur ${ }^{2}$ \\ Metin Ateş ${ }^{3}$ \\ Ertuğrul Tarcan ${ }^{4}$
}

\begin{abstract}
Evaluating the services of public hospitals in medical tourism in our country, to create data structures to improve. The research is descriptive and field research. The questionnaire was used as data collection tool. The population of the research was public hospitals in İstanbul. It has yet to determine the sample. All were included in the study of the universe. Surveys have been applied to the hospital executives face to face. Serving a total of 62 public hospitals in Istanbul has reached 60 from the administrator. Data were analyzed by SPSS software package was used. Demographic information obtained as a result of the implementation of the survey percentage (\%) and number of people (n) taking statements have been prepared. In the analysis of data obtained from the survey; frequency distribution, mean, standard deviation, chi-square $\left(\chi^{2}\right)$ test was conducted as required statistical analysis. According to the research findings; from abroad, especially from June to July and August in the patients (86.7\%) were admitted to hospitals and reference is made to themselves $(90 \%)$ were determined. Patients are often admitted to the eye and obstetric services (40\%), the majority $(91.7 \%)$ of the patients and $46.7 \%$ from the Turkish Republic of Germany. If Turkey is found to be effective in the choice of the price with a rate of $96.7 \%$. These results indicate that the desired level yet in the public hospitals of health tourism.It shows that we are more advanced in their health tourists. Foreign patients, especially the Public Hospitals have to choose when they come to Turkey. Choice of hospital activity in patients, beds, staff and a similar number of properties have been found to be no effect. When assessing overseas promotion activities for both types of hospital patients it has been identified where there aren't serious efforts. For this purpose, the Internet, magazines, newspapers, brochures or tour operators visit methods were used. In our country, it is necessary to increase the awareness level of the public hospitals in medical tourism. Management and organization structure, together with physical conditions must arrange accordingly. Need to develop promotional activities. For this, they need to do serious work with academics and industry representatives of the relevant ministries.
\end{abstract}

Key words: health tourism, medical tourism, public hospitals

\section{INTRODUCTION}

Medical tourism, defined as surgery or other medical treatments in order to travel. Medical tourism involves two basic topics including surgery and therapy. There is a distinct difference between the two. Surgical tourism necessarily require specific operation. Therapeutic aimed at improving methods of treatment used in tourism. Therapy is a little different from the surgery. There are similar aspects such as medical examination and diagnosis. However, this treatment different from surgery requires longer and continuous control. (Smith and Puczko, 2009: 101-102).

\footnotetext{
${ }^{1}$ Assistant Professor, Mediterrain Univercity, Antalya, Turkey.

${ }^{2}$ Msc, Ministry of Health, Turkey.

${ }^{3}$ Professor, Department of Health Management, Faculty of Health Sciences, Marmara University, İstanbul, Turkey.

${ }^{4}$ Professor, Istanbul Univercity, İstanbul, Turkey.
} 
Medical sector and the results of jointly producing goods and services in the tourism sector have emerged in medical tourism. (Silver and the Great, 2008: 435). Medical tourism, more economical and the treatment, processing and quality health care for less waiting time is to go from one country to another. Medically from one country to another to avoid spa treatments are also needed medical tourism. (Aydin, 2008: 6). To go to another country to obtain health care is not a new thing. . However, the concept of medical tourism has emerged in the last 10-15 years. (Yanos, 2008: 16). Includes all concepts to the general concept of health tourism, remain healthy and fit. Medical tourism is for medical intervention and treatment (Brick, 2008: 8). In medical tourism, "tourists" are intended to be primarily medical treatment. However, the rest of the attractions, leisure activities, such as participating in the traditional tourism assessment (Mugomb and Danelle, 2007: 1).

It is possible to separate the history of medical tourism into two categories. The most prominent feature of the old-fashioned medical tourism is expensive. In this system, wealthy patients belonging to poor countries have suffered from the high treatment costs and transportation difficulties in Europe and America. However, they were receiving a higher quality of medical service. . New procedures in the medical tourism facilitated travel between the north-south and south-south and is so advanced that even medical tourism. To explain with a longer Examples Hindus can go for the treatment of unexpected decrease in body mass to America. A Bangladeshi can go to Thailand for the treatment of varicose veins. Therefore, the patient is no longer flow only from the third world to the first world. As from the third world to the third world it can take place in the form of the first world to the third world (Reisman, 2010: 29).

Asian countries are dominant in the medical tourism market worldwide. India in particular has an important place in the market with low prices. Medical tourism market demand is concentrated in three regions. North America, Western Europe and the Middle East. The distribution of the demand for destinations in these areas is as follows. European medical visitors's favorite countrys India, Malaysia and Thailand. Dominate the Middle East market because of the Malaysian Islamic reference. Singapore, the main destination of the Japanese mark Cuba is directed to the Central American market. Asian region is the most important continent for medical tourism. District attracts 1.3 million medical tourists annually (Health Foundation of Turkey, 2010: 47).

Mostly eye surgery in Turkey within the scope of medical tourism, dental surgery, in vitro fertilization practices, aesthetic and plastic operations, services for the treatment of heart and vascular disease, are presented. (Akdur, 2009: 40). Patients usually comes from England, Holland, Belgium, Russia, Bulgaria, Romania, Kosovo and Syria (Stephanou, 2009: 15). Medical and health services in developed countries like U.S. or Great Britain is expensive. European and American patients due to expensive treatment and long waiting periods in the insurance go to Thailand, India or other southeast Asian countries. In Asia, despite the lack of valid insurance services to foreigners, many foreigners seeking medical help because of price differences in this part of the world (Garcia and Besing in 2006: 42). The most important area in medical tourism, Asia is continent. Zone has attracted 1.3 million medical tourists annually. India is considered as the center of medical tourism. Nigerian for citizen spends $\$ 2$ billion a year for medical expenses outside the country. In Thailand tourism movement began in the 1970s with the sex-change operations. Later aesthetic surgery came to the foreBAKA, 2011: 6). Jordan, since the 1970s in the Middle East and Asia, the healthcare industry has been ahead of the country. In this regard, the country is the world's fifth. (Lightning and Altunkaya, 2006: 1; Ozturk, 2011: 50). 
Medical tourism is fast and big changes in the world. Especially in developing countries, stable and high income source in the search for fragile economies, are turning to outside sources of income such as exports and tourism. Due to various shortcomings in the social security services and proecedures developed countries, medical tourism is seen as an important source of revenue (Yavuz, 2010:6).

\section{RESEARCH}

\section{Aim of the study}

Evaluating the services of public hospitals in medical tourism in our country, to create data structures to improve.

\section{Methods}

The research is descriptive and field research. The questionnaire was used as data collection tool. The research population consisted of public hospitals in the province İstanbul. All were included in the survey universe. Surveys have been applied to the hospital executives face to face. Serving a total of 62 public hospitals in Istanbul has reached 60 from the administrator.

The questionnaire used in the research field consists of two parts. The first section consists of 13 questions and descriptive information about the hospital administrator. 34 guestion in the second part of the research relates to health tourism. 12,14-23,26-28,30-31 and 34-47 survey questions used in the form of the question Yalcin (Yalcin, 2006) is taken from the thesis.

\section{Data Analysis}

In data analysis software package SPSS was used. In the analysis of data obtained from the survey; frequency distribution, mean, standard deviation, chi-square $(\chi 2)$ test analysis were performed.

\section{FINDINGS}

The results of the studies performed are listed as follows:

Patients from abroad has used health services provided by hospitals, especially in JuneJuly-August (86.7\%).

Applicants have themselves foreign patients.

Patients have often resorted to eye and gynecological diseases.

The majority of patients of the Republic of Turkey, Germany, İran are from.

Especially in choosing Turkey it shows that prices are effective.

Public hospitals are specifically selected by foreign patients. 
The hospital's activities during the year, bed capacity, number of employees and similar issues are not effective in the preferences.

They came to Turkey for vacation and illness in an emergency or health problems because it is understood that apply to the nearest health facility.

The promotion activities for overseas patients it was seen on the internet. Magazine, newspaper, brochure or tour operators visit methods aren't preferred.

Promotional activities aren't carried out in hospitals.

According to hospital administrators, only $13,3 \%$ of the hospitals surveyed health tourism unit has been created.

According to the hospital director, the automation system for foreign patients has not been established in the majority of hospitals surveyed.

According to the hospital director, foreign language skills of employees $70 \%$ of the hospitals surveyed are insufficient.

According to hospital administrators, hospital software package for treatment of foreign patients has not been established in $94 \%$ of surveyed.

According to hospital administrators, guidance for foreign patients only $26.7 \%$ of the hospitals surveyed and warning signs were developed.

According to the hospital director, the hospitals surveyed posters and leaflets for patients only $23.3 \%$ foreigners were created.

According to the hospital director, hospital facilities only in accordance with the reputation of $23.3 \%$ of the patients belonging to different religious faith has been provided.

According to hospital administrators, the most important factor in choosing the Turkey of foreign patients (96.7\%) was the price.

According to hospital managers (96.7\%), insufficient promotion services for foreign patients.

According to the hospital director, human resources and physical and technological infrastructure to provide services to foreign patients in hospitals in the survey is not enough.

None of the hospitals involved in this study were found to have contracted interpreter.

None of the hospitals for foreign patients involved in this study there is no reserved floor.

Only $16.7 \%$ of applications from foreign patients to the hospital by insurance companies. 
Foreign patients to the hospitals surveyed had applied for most eye diseases $(41.7 \%)$. Secondly, for gynecology (40\%) and thirdly to respiratory diseases $(38.3 \%)$ were admitted.

Hospital executives, foreign patients admitted to hospitals suffer from various problems that they had with the insurance company.

Insurance companies, rates, accreditation, payback time and have experienced problems with patients provisioning issues.

Hospital managers have often said that foreign patients come to the hospital in the spring. The patient application is at least the winter months.

\section{CONCLUSION}

According to the research findings; from abroad, especially from June to July and August in the patients $(86.7 \%)$ were admitted to hospitals and reference is made to themselves $(90 \%)$ were determined. Patients are often admitted to the eye and obstetric services $(40 \%)$, the majority $(91.7 \%)$ of the patients and $46.7 \%$ from the Turkish Republic of Germany. If Turkey is found to be effective in the choice of the price with a rate of $96.7 \%$. These results indicate that the desired level yet in the public hospitals of health tourism.It shows that we are more advanced in their health tourists. Foreign patients, especially the Public Hospitals have to choose when they come to Turkey. Choice of hospital activity in patients, beds, staff and a similar number of properties have been found to be no effect. When assessing overseas promotion activities for both types of hospital patients it has been identified where there aren't serious efforts. For this purpose, the Internet, magazines, newspapers, brochures or tour operators visit methods were used. In our country, it is necessary to increase the awareness level of the public hospitals in medical tourism. Management and organization structure, together with physical conditions must arrange accordingly. Need to develop promotional activities. For this, they need to do serious work with academics and industry representatives of the relevant ministries.

\section{REFERENCES}

Akdur, S.A.(2009). Sağlık turizmi kapsamında medikal turizm ve Türkiye'deki uygulamalar üzerine bir araştırma; İstanbul ve Ankara örneği, Yayınlanmamış Yüksek Lisans Tezi, Gazi Üniversitesi Eğitim Bilimleri Enstitüsü Turizm İşletmeciliği Ana Bilim Dalı, Ankara.

Aydın, D.(2008). Türkiye'de sağlık turizmi ve Ortadoğu'daki yeri. Sağlık turizmi bülteni, Sayı:5, Eylül- Ekim, Yı1:1, Ankara.

Batı Akdeniz Kalkınma Ajansı (BAKA).(2011). Sağlık Turizmi Sektör Raporu Garcia, A.G., Besinga C.A.(2006). Challenges and opportunities in the Philippine medical tourism industry. The SGV review,4,1,June.

http://www.ey.com/global/download.nsf/Philippines/SGV_Review_June_2006/\$file/sgvre view_june2006.pdf Erişim Tarihi:21.01.2013 
Gençay, C.(2007). Sağlık turizmi, (Ed.) Bulu, M., Eraslan İ.H., Sürdürülebilir rekabet avantajı elde etmede turizm sektörü, İstanbul, Kazancı Hukuk Yayımevi.

Gümüş, F., Büyük, Ö.(2008). Sağlık turizminde yeni açılımlar: Tıp turizmi, III. Balıkesir Ulusal Turizm Kongresi, Kongre Bildiri Kitab1, Balıkesir, (17-19 Nisan), Ankara, Nobel Yayın Dağıtım.

Kiremit, A.Ş.(2008). Turizmin gelişiminde bir alternatif olarak medikal turizm: Bir sağlık kuruluşunda araştırma, Gazi Üniversitesi Eğitim Bilimleri Enstitüsü Turizm İşletmeciliği Anabilim Dalı, Yüksek Lisans Tezi, Ankara.

Mugomba, C., Caballero S.D. (2007). Medical Tourism and its opportunities: A conceptual framework for entry into the industry tourism and hospitality managemet, Master Thesis, Göteborg: School Of Bussiness, Ekonomics and Law Göteborg University.

Öztürk, M. (2011). Termal konaklama işletmelerinde yöneticilerin stratejik kalite yönetimi algıları: Afyon bölgesinde bir uygulama, Yayınlanmamış Yüksek Lisans Tezi, Düzce Üniversitesi Sosyal Bilimler Enstitüsü, Bolu.

Reisman, D.(2010). Health tourism social welfare through international trade, Cheltenham, Edward Elgar Publishing.

Stephano, R.M.(2009). Türkiye raporu. Sağlık turizmi bülteni, 8. Erişim Tarihi:10.01.2013

Türkiye Sağlık Vakfı, (2010). Dünyada ve Türkiye'de sağlık turizmi durum analiz raporu ve çözüm önerileri, Ankara, Efil Yayınevi.

Yanos, M.(2008). Denizaşırı ülkelerde cazip sağlık hizmet Aranıyor. Sağlık turizmi bülteni,5.

Yavuz, M.C.(2010). Sağlık turizminde destinasyon yönetimi: Adana modeli, Mehmet Kemal Dedeman Araştırma ve Geliştirme Proje Yarışması.

Yıldırım, H.H., Altunkaya, Ü.(2006). Türkiye'nin sağlık turizmi potansiyeli ve güçlükler http://www.absaglik.com/saglik_turizmi_turkiye.pdf. Erişim Tarihi: 25.12.2012. 